\title{
Flow Szinkronizáció Kérdôív: az optimális élmény mechanizmusának mérése társas interakciós helyzetekben
}

\author{
MAGYARÓDI TÍMEA* - OLÁH ATTILA \\ Eötvös Loránd Tudományegyetem, Pszichológiai Intézet, Budapest
}

(Beérkezett: 2015. március 15.; elfogadva: 2015. július 18.)

\begin{abstract}
Elméleti háttér: Az optimális élmény (áramlat, flow) különböző helyzetekben való vizsgálata széles körú kutatási területté vált a pozitív pszichológiában, azonban az interakciókban való múködésmódja továbbra is megválaszolandó kérdést jelent. Cél: Az áramlat-élmény dinamikájának kihívást jelentő, interakciós helyzetekben való kvantitatív vizsgálatának támogatására célunk a Flow Szinkronizáció Kérdőív (FSZK) kidolgozása. Módszerek: A méróeszköz fejlesztése racionális és empirikus tesztszerkesztési hagyományokat is követ. A kérdốiv kidolgozása az elméleti alapon létrehozott tételsor után négy empirikus vizsgálat során valósult meg, melyekben összesen 2077 felnôtt vett részt (két laboratóriumi kísérlet: $\mathrm{N}_{1}=60 ; \mathrm{N}_{2}=100$; két kérdóíves kutatás: $\mathrm{N}_{3}=358 ; \mathrm{N}_{4}=1709$ ). Eredmények: Az eredmények szerint a végsô, 28-tételes méróeszközt öt jól interpretálható faktor alkotja, melyek a közös feladatmegoldáshoz kapcsolódó flow-élményre, valamint a motivációs és koordinációs (feladat- és kapcsolatfókusz) aspektusokra vonatkoznak: 1. Hatékonyság és összehangoltság a partnerrel (12 tétel); 2. Bevonódás-élmény és koncentráció (5 tétel); 3. Motiváció és pozitív hatás a partnerre (3 tétel); 4 . Motiváció és tanulás a személy számára (4 tétel); 5 . Koordináció a partnerrel a tevékenység közben (4 tétel). A skálák belsố konzisztenciája megfelelő. A kérdőív látszatérvényessége elfogadható, az áramlat-élményhez kapcsolódó konvergens validitása megfeleló, a skálák a flow-élmény faktoraival közepes mértékú együttjárást mutatnak. Következtetések: A FSZK kidolgozása hozzájárulhat a flowszinkronizáció konstruktumának operacionalizálásához és a társas flow-élmények jövốbeni empirikus vizsgálatához.
\end{abstract}

Kulcsszavak: áramlat, flow-szinkronizáció, interakció, kérdőív-fejlesztés

\section{Elméleti háttér}

A pozitív pszichológiai megközelítés (Seligman \& Csikszentmihalyi, 2000) azokra a faktorokra koncentrál, amelyek az embereket - akár individuális, akár csoportos szinteken - elvezethetik a mentális egészséget, azaz az optimális múködést jelző virágzás (Keyes, 2002) állapotába. Egyéni szinten a pozitív pszichológia egyik célja, hogy az optimális élményt (áramlat,

\footnotetext{
* Levelező szerző: Magyaródi Tímea, Eötvös Loránd Tudományegyetem, Pszichológiai Intézet, 1064 Budapest, Izabella u. 46. E-mail: magyarodi.timea@ppk.elte.hu
} 
flow) tanulmányozza, amely egy olyan szubjektív állapotot jelöl, amelyben a személy teljes mértékben bevonódik egy kihívást jelentó, aktív tevékenységbe (Csikszentmihalyi, 1990).

Az áramlat-élményt kutatók hosszú vitákat folytatnak a flow-élmény feltételeire, kísérótényezóire és az élménycsatornából való kilépéskor tapasztalt pozitív érzelmek elkülönítésére vonatkozóan (pl. Engeser, 2012). Korábbi elképzelések szerint (pl. Jackson, Thomas, Marsh, \& Smethurst, 2001) a flow-élmény feltételei (kihívás-készség egyensúlya, tiszta cél, folyamatos visszajelzés) nem különülnek el a flow dinamikájáról, természetéról szóló tényezóktól, amelyek már magát az élményt annak megjelenése után jellemzik (pl. idóérzékelés megváltozása, kontrollérzés a tevékenység felett, éntudatosság elhalványulása). Nakamura és Csikszentmihalyi (2002) megfogalmazása szerint azonban alapvetően el kell különítenünk a flow-élmény kiváltó tényezóit a kísérójelenségeitól. Az utóbbi években megjelent az áramlat-élmény biológiai hátterének azonosítására vonatkozó kutatási irány, mely magában foglalja a sikeres flow-indukció kérdéskörét is, melyhez az áramlat három alapvetô feltételét veszik alapul (pl. Ulrich, Keller, Hoenig, Waller, \& Grön, 2014).

Korábbi kutatások szerint a flow univerzális élmény, mivel a múködése minden esetben ugyanolyan, kultúrától, nemtól, kortól, foglalkozástól, vagy bármely egyéb faktortól függetlenül (Massimini \& Delle Fave, 2000). Annak ellenére, hogy az élmény bármilyen tevékenységben átélhető, ha az a flow feltételeit teljesíti (az észlelt kihívások és készségek közötti egyensúlyt, a tiszta célt és a pontos, azonnali visszajelzést; Nakamura \& Csikszentmihalyi, 2002), egyéni különbségeket találunk azonban az élményt indukáló tevékenységekben (pl. Csikszentmihalyi \& LeFevre, 1989; Moreno Murcia, Cervelló Gimeno, \& González-Cutre Coll, 2008). A flow-élmény különbözó kontextusokban való kutatásához kapcsolódóan számos olyan megjegyzés olvasható, amely az élmény társas helyzetekben való átélését emeli ki (Csikszentmihalyi \& Csikszentmihalyi, 1988; Walker, 2010). Nakamura és Csikszentmihalyi (2002) értékelése szerint az áramlat közös tevékenységekben való vizsgálata egyelőre hiányos, így szükség van olyan kutatásokra, melyek a flow tanulmányozását közös tevékenységekre is kiterjesztik, az élmény társas dimenzióinak, dinamikájának vagy feltételeinek feltárására vonatkozóan.

Jelen munkával célunk a flow interperszonális vizsgálatához való kapcsolódás, melynek érdekében bemutatjuk a Flow Szinkronizáció Kérdőív (FSZK) mint önbeszámolós méróeszköz kidolgozási folyamatát. Az eszköz célja a flow-szinkronizáció mint a flow közös élményekhez kapcsolódó hipotetikus mechanizmusának értékelése, és ezáltal a flow-élmény társas dimenzióinak megragadása. 
Az áramlat-élmény mérésére számos méróeszköz és értékelési eljárás került kidolgozásra, melyek típustól függóen különböző célokat szolgálnak a jelenség kutatásában (Moneta, 2012). Az interjú-módszerek jellemzóen feltáró fókuszúak, céljuk a flow természetének megértése (Hefferon \& Ollis, 2006; Swann, Keegan, Piggott, Crust, \& Smith, 2011). A flow kutatások kezdetekor Csikszentmihalyi jellemzóen interjú módszerrel végzett vizsgálatokra alapozta elsó hipotéziseit, eredményeit (Csikszentmihalyi, 1990). A következó jellemző technika az élményértékelő mintavételi eljárás (Experience Sampling Method: ESM), mely a hétköznapi élmények leírását célozza meg, így széleskörúen alkalmazott módszert jelent a flow különböző kontextusokban való kutatásához (Csikszentmihalyi \& Larson, 1987). A vizsgálati eljárások harmadik csoportját pedig a papír-ceruza tesztek jelentik, melyek alkalmazásának célja, hogy mennyiségi módon mérhetôvé tegyék a flow dimenzióit és feltárják az optimális élmény előfordulásához kapcsolódó esetleges különbségeket (Nakamura \& Csikszentmihalyi, 2002).

A flow szociális helyzetekben való vizsgálata egy egyre növekvő kutatási területet jelöl; mégis az eddigi hipotézisek az áramlat társas múködésére vonatkozóan leginkább olyan kutatások melléktermékei, melyek inkább az élmény egyéni vonatkozásaira koncentrálnak. Számos leírást (Novak \& Hoffman, 1997) tartalmazó méróeszközt (amelyben a résztvevók elsóként egy leírást olvasnak a flow-élményról, majd meghatározzák azt a helyzetet, amelyben az olvasott élményt megtapasztalják, ezután értékelik is azt különböző élménydimenziók mentén; pl. Walker, 2010), interjút (Csikszentmihalyi \& Csikszentmihalyi, 1988) és egyéb flow-t méró eszközt (pl. Bakker, 2008) alkalmaztak eddig társas helyzetekben, azonban ez idáig inkább a flow individuális komponenseit monitorozták. Az eljárások közül kiemelendô az Elköteleződés Kérdôív (Engagement Questionnaire; Salanova, Peiró, \& Schaufeli, 2002), melynek bevonódást mérő skáláját (a kapcsolódó dimenziókkal együtt: életeró, elköteleződés, elmerülés) Salanova, Rodríguez-Sánchez, Schaufeli és Cifre (2014) megbízható, kvantitatív méróeszközként alkalmazták a csoportos munkában való elköteleződés mérésére. A következő rövid áttekintó táblázat bemutatja a szakirodalom összefoglalását (1. táblázat), amely alapján elmondható, hogy mindeddig egyetlen, specifikus interakciós folyamatokra koncentráló, áramlat-élményt méró eszköz sem került kidolgozásra és alkalmazásra.

Az 1. táblázatban összefoglalt elképzelések tehát leginkább megfigyelések és előzetes hipotézisek eredményei. Vizsgálatainkban ezért célunk a flow-kutatás új, társas irányához kapcsolódni, az áramlat társas helyzetben való tanulmányozását pedig azokkal az elméletekkel alapozzuk meg, melyek a közös flow-élmények mechanizmusát képesek lehetnek magyarázni. 
1. táblázat. A flow vizsgálata társas helyzetekben és az alkalmazott méróeszközök

\begin{tabular}{|c|c|c|c|}
\hline Szerző(k) & Konstruktum & Méróeszköz & A méróeszköz tartalma \\
\hline $\begin{array}{l}\text { Csikszentmihalyi \& } \\
\text { Csikszentmihalyi } \\
(1988)\end{array}$ & Megosztott flow & $\begin{array}{l}\text { Félig strukturált } \\
\text { interjú }\end{array}$ & $\begin{array}{l}\text { Alapleírások a flow és } \\
\text { antiflow } \\
\text { állapotokról. } \\
\text { Az egyes feltételek } \\
\text { alapos vizsgálata }\end{array}$ \\
\hline Bakker (2005) & Flow-transzfer & $\begin{array}{l}\text { Munkához kapcso- } \\
\text { lódó Flow Leltárja } \\
\text { (Work-related Flow } \\
\text { Inventory, Bakker, } \\
\text { 2008) }\end{array}$ & $\begin{array}{l}\text { Skálák: Belemerülés, } \\
\text { A munka élvezete, } \\
\text { Intrinzik munka- } \\
\text { motiváció }\end{array}$ \\
\hline Walker (2010) & Szociális flow & $\begin{array}{l}\text { Egyéni és társas } \\
\text { flow-élmény leírása }\end{array}$ & $\begin{array}{l}\text { Két tevékenység } \\
\text { leírása. } \\
\text { Az élmények értékeló- } \\
\text { skálája (7-fokú } \\
\text { Likert-skála az öröm } \\
\text { jelzésére) }\end{array}$ \\
\hline $\begin{array}{l}\text { Salanova és } \\
\text { mtsai (2014) }\end{array}$ & $\begin{array}{l}\text { Együtt átélt } \\
\text { flow-élmény - } \\
\text { kollektív flow }\end{array}$ & $\begin{array}{l}\text { Önbeszámolós } \\
\text { kérdôív az } \\
\text { élményrôl }\end{array}$ & $\begin{array}{l}\text { Csoportos feladatba } \\
\text { való belemerülés skála, } \\
\text { Csoportos élvezet skála, } \\
\text { Csoportos kihívás, } \\
\text { Csoportos készség } \\
\text { skála }\end{array}$ \\
\hline $\begin{array}{l}\text { Gaggioli, Milani, } \\
\text { Mazzoni, \& Riva } \\
\text { (2011) }\end{array}$ & Hálózati flow & $\begin{array}{l}\text { Elméleti hipotézis, } \\
\text { empirikus tesztelés } \\
\text { nélkül }\end{array}$ & - \\
\hline Sawyer (2007) & Csoportos flow & $\begin{array}{l}\text { Elméleti hipotézis, } \\
\text { empirikus tesztelés } \\
\text { nélkül }\end{array}$ & - \\
\hline $\begin{array}{l}\text { Moore, Drake, } \\
\text { Tschannen-Moran, } \\
\text { Campone, \& Kauf- } \\
\text { mann (2005) }\end{array}$ & Kapcsolati flow & $\begin{array}{l}\text { Elméleti hipotézis, } \\
\text { empirikus tesztelés } \\
\text { nélkül }\end{array}$ & - \\
\hline
\end{tabular}

Korábbi eredmények szerint a legerősebb élményeink megosztottak (Whalen, 1998), és számos vizsgálat hangsúlyozza az interakciós helyzetekben való koordináció intenzitásnöveló szerepét, kiemelve továbbá az érzelmi, viselkedéses, pszichofiziológiai jelzések szinkronizációjának fontosságát a társas interakciókban, az interperszonális tapasztalatok hozzáadott értékének hangsúlyozásával.

A kapcsolódó elképzelések a következók: az érzelmi fertózés elmélet (Hatfield, Cacioppo, \& Rapson, 1994); a szociális koordinációs elmélet (Ackerman \& Bargh, 2010); az interakciós szinkronitás (Bernieri \& Rosent- 
hal, 1991); a társas referencia (Campos \& Sternberg, 1981) és interszubjektivitás elképzelése (Trevarthen, 1980); az együttes élmény (Mérei, 1947); a kooperatív tanulás (Johnson, Johnson, Holubec, \& Roy, 1984) és az énkiterjesztés elmélet (Aron \& Aron, 1986). Számos neurobiológiai (Bauer, 2012) eredmény született arra vonatkozóan, hogy az embereket alapvetóen együttmúködés és szociális rezonancia jellemzi; leginkább a dopamin mint a motivált cselekvést indító ingerületátvivó anyag, valamint az oxitocin (amely a tartós kapcsolatok kialakításáért felelốs neurotranszmitter) szerepét emelik ki a kutatások. A tükörneuronok múködése (Semin \& Cacioppo, 2008) és az agyegységesítés jelensége (Hasson, Ghazanfar, Galantucci, Garrod, \& Keysers, 2012) támogatja továbbá azt az elképzelést, hogy a valós idóben történó, valós interakciós helyzetek támogatják leginkább a szinkronizációs folyamatot, a perceptuális ingerlés minél több modalitásban való megjelenésével együtt. Fredrickson (2013) a pozitív érzelmek, a szeretet neurológiai magyarázatához kapcsolja az elóbbi jelenségeket.

A szakirodalomban a szinkronizáció kutatásának több iránya is ismert, a szinkronizált interakciós mintázatok jelensége régóta áll a nonverbális viselkedésre koncentráló kutatások középpontjában, így számos interakciós kapcsolatra vonatkozóan születtek elképzelések a múködéséról (Ramseyer \& Tschacher, 2010), valamint számtalan definíciót is eredményezett a vizsgálatok sokszínúsége. Az egyik fô különbség a szinkronizáció-kutatásokban a statikus és dinamikus jellemzók (pl. Ramseyer \& Tschacher, 2008) megragadásában és a kontextuális alapegységek kiemelésében (Ramseyer \& Tschacher, 2010) van. Az interakciós kapcsolatokban, a kommunikációban részt vevő felek aktívak, hatnak egymás viselkedésére, a partner folyamatosan változó akcióihoz illeszkedve, ami szinkronicitáshoz vezethet (Dumas, Nadel, Soussignan, Martinerie, \& Garnero, 2010). A szinkronizáció a kapcsolat aktuális állapotának pozitív megítélésében és fenntartásában (Tschacher, Rees, \& Ramseyer, 2014) egyaránt alapvetó szerepet tölt be, és ha a tevékenység végzése során megjelenik, akkor az együttmúködési hajlandóságot növeli (Delaherche és mtsai, 2012).

Az elóbbi koncepciók felvetik annak lehetôségét, hogy a pszichológiai mechanizmusok automatikusan, erófeszítés nélkül koordinálódhatnak, ezáltal elképzelhetónek tartjuk, hogy az élmények vagy szubjektív állapotok szinkronizációja is lehetséges lehet egy közös, együttmúködó aktivitás végzése során, mely az élmény intenzitásának növekedéséhez vezethet. A flow társas interakcióban létrejövő mechanizmusának vizsgálatához a szinkronizáció-kutatás (Ramseyer \& Tschacher, 2008) fogalmait használjuk: feltételezzük, hogy valós interakciós helyzetekben létrejöhet a közös célért végzett tevékenységben részt vevők áramlat-élményének szinkronizációja, mely az élmény intenzitásának növelésében, az élmény hosszának 
megnyújtásában is segíthet. Elképzelésünk szerint a flow-szinkronizáció jelölheti azt a jelenséget, amelyet egy kihívást jelentó, bevonódást keltó közös, interaktív feladatmegoldó helyzetben figyelhetünk meg a résztvevốk között.

A flow-szinkronizáción mint múködési mechanizmuson keresztül a személy és környezet interakcionista alapú rendszere (Nakamura \& Csikszentmihalyi, 2002) kiterjeszthetô egy másik személlyel, aki a környezet részét képezve lehetséges facilitátora lehet a partner flow-élményének, dinamikus kölcsönhatásban együttmúködve vele, reciprok viszonyban dolgozva a közös cél elérésén a partnerrel. A flow-élmény interaktív, szociális szituációban való vizsgálata ellenére továbbra is szubjektív állapotnak tekinthetó, azonban feltételezzük, hogy a társas helyzetben megjelenó kísérô elemek megragadásával az eredeti flow-elmélet (Csikszentmihalyi, 1990) kiterjeszthetố lehet.

A flow és pszichológiai koordinációs elméletek áttekintésével, a flowszinkronizáció definíciójaként tehát a következó meghatározást javasoljuk: a flow-szinkronizáció azt a teljes körú pszichológiai mechanizmust jelenti, amikor a partnerek egy valós interakcióban olyan közös, tiszta célért dolgoznak, amely magas, de teljesíthetô kihívást jelent számukra, tehát a tevékenység teljesíti a flow-élmény feltételeit (Csikszentmihalyi \& Csikszentmihalyi, 1988; Walker, 2010), a részt vevố tagok kooperálnak egymással a közös cél eléréséért és reagálnak egymásra a feladat megoldása céljából. Az együttmúködés során feltételezhetóen készségmegosztás történik a cél eléréséért, a másik személy visszajelzést jelent a résztvevók számára, így az emergens motivációt (Csikszentmihalyi, Abuhamdeh, \& Nakamura, 2005) is támogathatja.

Jelen munkában a Flow Szinkronizáció Kérdőív kidolgozásának folyamatát ismertetjük, mely a flow-szinkronizáció mérésének, a közös célért végzett feladatban átélt flow-élmény dinamikájának mögöttes mechanizmusának megragadására alkalmas eszköz lehet. Alapvetô célunk szerint a kérdốiv a flow-elmélet és a pszichológiai koordinációs és szinkronizációs elméletek alapján, empirikus tesztfejlesztési módszerekkel, a tesztfejlesztési protokoll (Cohen \& Swerdlik, 2009) követésével, négy különbözó vizsgálaton keresztül került kialakításra. Mivel a flow-szinkronizáció egy kialakításra váró konstruktum, így a vizsgálatban részt vevô személyek megjegyzései a látszatérvényességre és a tételek tartalmára vonatkozóan is támogatták a munkát. A flow-elmélet (Csikszentmihalyi, 1990) kitágítását támogató cél eléréséhez két laboratóriumi, majd két kérdóíves vizsgálat járult hozzá. A négy vizsgálat a társas, kihívást jelentố szituációkban megjelenó flow-élményre fókuszált, melyekben a mérôeszköz különbözô verziói kerültek tesztelésre és kiegészítésre a végső verzió eléréséig. 
A kérdóív utolsó verziója alkalmas volt a jelen cikkben tárgyalt hipotetikus konstruktum, a flow-szinkronizáció latens struktúrájának feltárására és a flow-élménnyel való konvergens validitásának tesztelésére. A munka eredménye egy 28-tételes, önbeszámolós, papír-ceruza kérdốiv, mely azokat a faktorokat kívánja mérni, amelyek szerepet játszanak az egyének flow-élményének dinamikus támogatásában, egy közös, kihívást jelentó tevékenységben, amelyben a két személy együtt dolgozik.

\section{Módszerek}

\subsection{Első vizsgálat}

\subsubsection{Minta}

Az elsó vizsgálatban 60 nói vizsgálati személy vett részt. A minta átlagéletkora 20,83 év (szórás =1,98 év). A résztvevók egyetemi kurzusokon keresztül jelentkezhettek, a részvétel önkéntes volt, és bármikor megszakítható. A mintavétel kényelmi módszerrel történt.

\subsubsection{Méróeszközök}

A partnerrel való közös feladatvégzés után a résztvevók online kérdóívet töltöttek ki, amely a tevékenység alatti élményeik minóségének mérését szolgálta. Jelen alfejezetben a FSZK elsó verziójára koncentrálunk.

Flow Szinkronizáció Kérdôív - elsố verzió (FSZK-20). A mérőeszköz a flowszinkronizáció mechanizmusának mérését célozza meg, mely a flow-elméleten (Csikszentmihalyi, 1990) és a társas interakciókhoz kapcsolódó koordinációs és szinkronizációs elméleteken (pl. Ackerman \& Bargh, 2010; Aron \& Aron, 1986; Campos \& Sternberg, 1981; Johnson és mtsai, 1984; Hatfield és mtsai 1994; Mérei, 1947; Trevarthen, 1980) alapul. A kérdóív konstrukciójának elsó lépésekor 20 tétellel dolgoztunk, mely tételek a fenti elméletek alapján, szakértők által kerültek kialakításra. Az első empirikus vizsgálat résztvevóinek az állításokat egy 5-fokú Likert-skálán (1: Egyáltalán nem - 5: Teljes mértékben) kellett értékelniük. Az elsó verzió tételeinek belsó konzisztenciája jó $(\alpha=.88)$ volt.

\subsubsection{Eljárás}

A vizsgálat első lépése egy, a személyiségjellemzókre rákérdezô online kérdôív kitöltése (a FSZK kifejlesztésében nem releváns a vizsgálatnak ez a lépése, így nem részletezzük), majd a laboratóriumi fázis következett. A laboratóriumi helyzet megtervezésekor olyan helyzetet választottunk, melyben létrejöhet a közös célért végzett feladatvégzés, továbbá az 
áramlat-élmény feltételei is teljesülhetnek, tehát feltételezhetóen létrejöhet egy olyan helyzet, melyben a flow-szinkronizáció tesztelhetó. A FSZK kidolgozásához hozzájáruló helyzetben a vizsgálati személyek páros teniszt játszottak egy Nintendo Wii játékkonzol segítségével (Wii Sports software, Tennis game), az ökológiai validitás biztosítása érdekében (McMahan, Ragan, Leal, Beaton, \& Bowman, 2011). A vizsgálati helyzetben két személy játszott együtt párosként a számítógép ellen. A vizsgálati személyek nem teniszeztek és nem játszottak Wii-vel korábban, továbbá nem ismerték egymást. A vizsgálati helyzet megtervezéséhez a flow-feltételek (Nakamura \& Csikszentmihalyi, 2002) minél valószínúbb teljesítése jelentette az alapot: a résztvevốk nem ismerték a játékot, a kihívás rendelkezésre állt, a cél a háromszettes játék megnyerése volt, visszajelzést a játékprogram biztosított a pontoknak és a játék állásának jelzésével, valamint az egyes akciók visszajátszásával.

A szorongás elkerülése érdekében a vizsgálati személyek egy bemelegító fázisban vettek részt, melyben elsajátíthatták a játékhoz szükséges készségeket. A bemelegítô fázis után a vizsgálati személyek beszámoltak arról, hogy szükségesnek érzik-e a további gyakorlást az eszközzel. Mindegyik résztvevố nemmel válaszolt a kérdésre, továbbá az egyéni beszámolók alapján a kihívás és a készségek szintjét is megfelelơnek ítélték a kísérletvezetố kérdésére; egyéni sajátosságok a helyzet által keltett kihívások és a saját, észlelt készségek szintjében nem mutatkoztak. A helyzet által keltett optimális kihívás és készségszint szubjektív jóváhagyása indokolta a játékhelyzet flow-indukciós aktivitásként való elfogadását. Ezután következett az éles játék fázisa, melyre vonatkozóan az egyéni és közös élménykomponenseket mértük a helyzet utáni kérdőív kitöltésével. Mivel a flow-szinkronizáció kialakítás alatt álló koncepció, így a vizsgálati személyekkel készített interjúk segítették a konstruktum definiálását is.

\subsection{Második vizsgálat}

\subsubsection{Minta}

A második vizsgálatban 100 vizsgálati személy vett részt összesen, 80 férfi és 20 nô. Az átlagéletkor 21,44 év volt (szórás =2,72), a résztvevók egyetemi kurzusokon keresztül jelentkezhettek, a részvétel önkéntes volt, és bármikor megszakítható. A mintavétel kényelmi módszerrel történt.

\subsubsection{Méróeszközök}

A 2. laboratóriumi vizsgálatban a partnerrel való közös feladatvégzés után a résztvevốk szintén online kérdóívet töltöttek ki, amely a tevékenység 
alatti élményeik minőségének mérését szolgálta. Jelen alfejezetben a FSZK második verziójára koncentrálunk.

Flow Szinkronizáció Kérdôív - második verzió (FSZK-42). A kérdőív második verziója 42-tételes. Az elsó kísérlet eredményeként 22 itemmel került a kérdőív kiegészítésre, a vizsgálatot záró interjún keresztüli megkérdezése alapján. A kitöltés módja megegyezik az első verzióéval. A FSZK-42 reliabilitása megfeleló $(\alpha=.93)$.

\subsubsection{Eljárás}

A második laboratóriumi vizsgálat eljárása megegyezik az első vizsgálatéval. Ez a kutatás az elsó kiterjesztéseként férfi és férfi-nói párokat tesztelt (33 férfi pár, 3 nói pár és 14 férfi-nói pár).

\subsection{Harmadik vizsgálat}

\subsubsection{Minta}

A harmadik vizsgálatban 358 vizsgálati személy vett részt $\left(\mathrm{M}_{\text {eletkor }}=24,85\right.$ év, szórás $=8,97$ év). Az önkéntes résztvevók elérése egyetemi kurzusokon és közösségi oldalakon keresztül történt, hólabda típusú mintavétellel.

\subsubsection{Mérôeszközök}

Jelen kérdőíves vizsgálat célja azoknak a tipikus társas tevékenységeknek a feltárása, amelyekben flow-élmény tapasztalható, a flow-szinkronizáció elemeivel együtt. A Flow Szinkronizáció Kérdóív második verziója (FSZK-42) struktúrájának teszteléséhez használtuk a méróeszközt ebben a vizsgálatban, amelyben a kérdóív belsó konzisztenciája szintén elfogadható volt $(\alpha=.95)$.

\subsubsection{Eljárás}

A harmadik vizsgálat lebonyolítása egy online kérdốives oldalon keresztül történt. A tájékoztatás és beleegyezó nyilatkozat kitöltése után a résztvevók lejegyezték a legtipikusabb interperszonális helyzetet, amelyben jellemzóen flow-élményt élnek át. A kérdőív egy nyitott kérdéses szekcióval zárult, amelyben a vizsgálati személyek további információkat adhattak a társas helyzetben átélt flow-élményhez kapcsolódó saját tapasztalataikról. 


\subsection{Negyedik vizsgálat}

\subsubsection{Minta}

A negyedik vizsgálatban 1709 felnôtt vizsgálati személy vett részt $\left(\mathrm{N}_{\mathrm{nó}}=\right.$ $1114 ; \mathrm{N}_{\text {férfi }}=595$ ). Az átlagéletkor 26,95 év volt (szórás = 11,23 év). A résztvevók egyetemi kurzusokon és közösségi média oldalon kerültek toborzásra, hólabda típusú mintavétellel.

\subsubsection{Méróeszközök}

A demográfia kérdések (nem, életkor, lakóhely, kapcsolati állapot, iskolai végzettség) után a résztvevók egy online kérdoóiven keresztül válaszoltak egyéni és társas flow-élményeikkel kapcsolatos kérdésekre.

Flow Szinkronizáció Kérdốiv - harmadik verzió (FSZK-39). A kérdớiv harmadik verziója 39-tételes. A 42-itemes verzió (FSZK-42) strukturális analízise után a megmaradt 26 tételt további 13 tétellel egészítettük ki, a harmadik vizsgálatban részt vevố vizsgálati személyek visszajelzése alapján. A 39-tételes mérőeszköz belső konzisztenciája magas $(\alpha=.94)$.

Flow Állapot Kérdốiv (FÁK; Magyaródi, Nagy, Soltész, Mózes, \& Oláh, 2013). A kérdôív az áramlat-élmény alapdimenzióit méri, 20 item segítségével. A résztvevók ötfokú Likert skálán értékelik az egyes állításokat (1: Egyáltalán nem értek egyet - 5: Teljesen egyetértek). A FÁK két alskálából áll: a 11-tételes Kihívás-készség egyensúly skálából (a flow-zónába lépés alapvetó feltételeire utal), a másik, Egybeolvadás az élménnyel skála 9 tételes, a flow kísérójelenségeit foglalja össze. A skálák reliabilitása elfogadható $\left(\alpha_{\mathrm{K}-\mathrm{K}}=.92 ; \alpha_{\mathrm{E}}=.91\right)$.

\subsubsection{Eljárás}

A kutatást az ELTE PPK Kutatásetikai Bizottsága hagyta jóvá (iktatási szám: 2014/13). A résztvevók online kérdőívet töltöttek ki az egyéni és társas helyzetekben megtapasztalható áramlat-élménnyel kapcsolatosan.

\section{Eredmények}

A méróeszköz kidolgozása négy lépésben, négy vizsgálaton keresztül történt (1.ábra), melyekben összesen 2227 felnótt résztvevő adatait dolgoztuk fel. Az elsó két laboratóriumi vizsgálat a fejlesztési folyamat empirikus alapú tételgyújtését szolgálták. Ahogy korábban ismertettük, a FSZK-20 a flow- és a koordinációs, szinkronizációs elméletek alapján került kidolgozásra, tehát az elsố lépés a racionális tesztszerkesztési hagyományhoz köthetô. A munka célja az volt, hogy a tételek tartalmában megjelenjenek a flow-élmény feltételei és jellemzói, továbbá az interakció során a partnerrel 

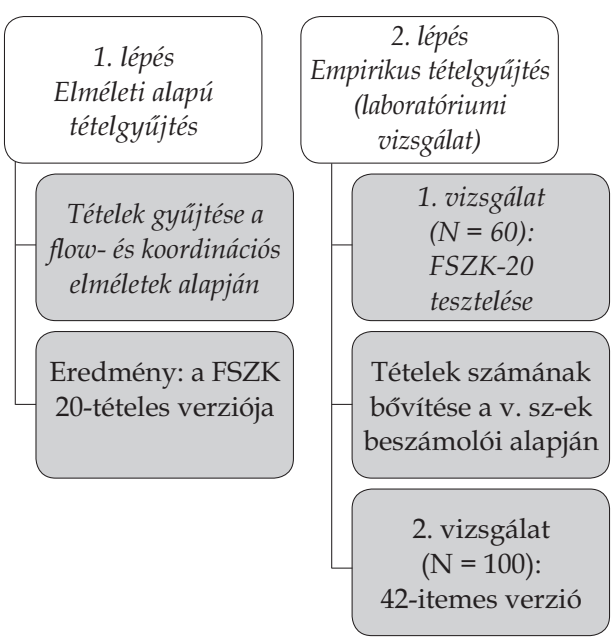

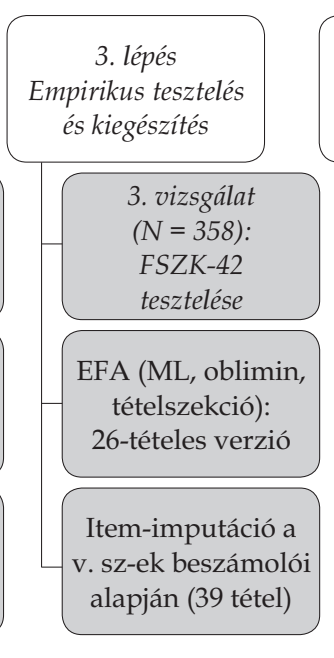

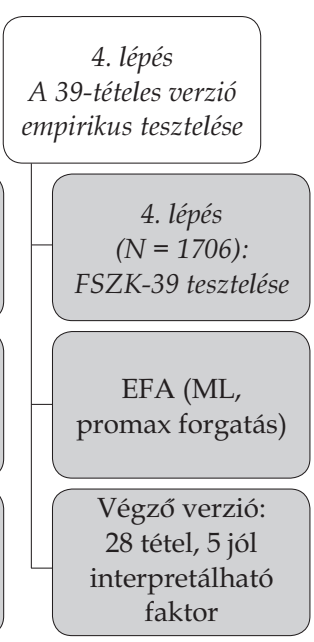

1. ábra. A Flow Szinkronizáció Kérdôív kidolgozásának folyamata (Megjegyzés: EFA = feltáró faktorelemzés; ML = maximum likelihood)

való kooperáció és koordináció. A kérdoóiv minden verziójának látszatérvényességét egy szakértối csoport és a vizsgálatok résztvevơii is tesztelték.

A következó, empirikus kutatások során további tételeket gyújtöttünk a vizsgálati személyek beszámolói alapján, így a méróeszköz-fejlesztésnek következó lépése már az empirikus tesztszerkesztési hagyományt követi. A közös laboratóriumi helyzet oly módon került kidolgozásra, hogy biztosítsa az optimális élmény feltételeit, ezáltal feltételeztük, hogy a flow-szinkronizáció mechanizmusa az indukált kontextusban tanulmányozható. A vizsgálati személyek által nyújtott visszajelzések a vizsgálat végén felvett interjúkban további inputot jelentettek a flow-szinkronizáció koncepciójának kidolgozásához. A 42-tételes verzió a kérdóív kipróbálására alkalmasnak bizonyult (Cohen \& Swerdlik, 2009), így a következő vizsgálatban elkezdtük az adatok elemzését a tételek letisztázása és a lehetséges latens struktúra feltárása céljából, feltáró faktoranalízis használatával.

A FSZK 42-tételes verziójának tesztelésére és a tételbankba nem illó itemek kizárásának céljából feltáró faktorelemzést végeztünk, maximum likelihood módszerrel, direkt oblimin $(\delta=0)$ forgatással. A kezdeti Kaiser-Meyer-Olkin $(\mathrm{KMO})$-mutató értéke $0.95(\mathrm{p}<0,001)$, a Bartlett-szfericitás-teszt szintén szignifikáns $\left[\chi^{2}(861)=9615,43 ; p<0,001\right]$, tehát a faktorelemzés megvalósíthatóságát támogatják. Mivel bizonyos tételek $(4 ., 34 ., 38)$ végsó kommunalitása alacsony volt $(<0,25)$, az elemzésbe nem kerültek be. Elsóként hat, 1-nél nagyobb sajátértékkel rendelkező faktort azonosított az elemzés. Bizonyos tételek több faktorra töltöttek (9., 11., 15., 22., 28., 30., 
2. táblázat. A FSZK 2. verziójához tartozó tételek faktortöltései és kommunalitásai $(\mathrm{N}=358)$

\begin{tabular}{|c|c|c|c|c|c|c|c|}
\hline & \multicolumn{6}{|c|}{ Faktortöltés } & \multirow{2}{*}{$\begin{array}{c}\text { Kommu } \\
\text { nalitás }\end{array}$} \\
\hline & 1 & 2 & 3 & 4 & 5 & 6 & \\
\hline $\begin{array}{l}\text { 21. Koordináltuk a viselkedéses } \\
\text { megnyilvánulásainkat. }\end{array}$ & 0,75 & & & & & & 0,49 \\
\hline $\begin{array}{l}\text { 1. Összhangban éreztem } \\
\text { a viselkedésemet a partneremével. }\end{array}$ & 0,73 & & & & & & 0,30 \\
\hline $\begin{array}{l}\text { 16. Azt éreztem, hogy szinte együtt } \\
\text { rezdülünk a partneremmel. }\end{array}$ & 0,71 & & & & & & 0,71 \\
\hline $\begin{array}{l}\text { 18. Egymás tükörképének éreztem } \\
\text { magunkat. }\end{array}$ & 0,69 & & & & & & 0,58 \\
\hline $\begin{array}{l}\text { 29. Éreztem a szinkront kettónk } \\
\text { között. }\end{array}$ & 0,54 & & & & & & 0,74 \\
\hline $\begin{array}{l}\text { 17. Csak a közös tevékenységre } \\
\text { koncentráltam. }\end{array}$ & 0,52 & & & & & & 0,46 \\
\hline 42. Teljesen kikapcsoltam. & 0,50 & & & & & & 0,40 \\
\hline $\begin{array}{l}\text { 36. Belefeledkeztem } \\
\text { a tevékenységbe. }\end{array}$ & 0,48 & & & & & & 0,47 \\
\hline $\begin{array}{l}\text { 13. Nem vettem figyelembe } \\
\text { a partneremet a feladat közben. }\end{array}$ & & 0,88 & & & & & 0,74 \\
\hline $\begin{array}{l}\text { 23. Nem vettem figyelembe a } \\
\text { partneremet a tevékenység közben. }\end{array}$ & & 0,75 & & & & & 0,59 \\
\hline $\begin{array}{l}\text { 26. Ellestem néhány fogást } \\
\text { a partneremtól. }\end{array}$ & & & 0,89 & & & & 0,77 \\
\hline 14. Tudtam tanulni a partneremtól. & & & 0,76 & & & & 0,71 \\
\hline $\begin{array}{l}\text { 27. A partnerem teljesítménye } \\
\text { ösztönzött. }\end{array}$ & & & 0,57 & & & & 0,61 \\
\hline $\begin{array}{l}\text { 24. Éreztem, hogy pozitívan hatok } \\
\text { a partnerem feladatvégzésére. }\end{array}$ & & & & $-0,83$ & & & 0,82 \\
\hline $\begin{array}{l}\text { 12. Éreztem, hogy pozitívan hatok } \\
\text { a partnerem teljesítményére. }\end{array}$ & & & & $-0,65$ & & & 0,71 \\
\hline $\begin{array}{l}\text { 25. Ösztönöztük egymást a közös } \\
\text { feladatmegoldás alatt. }\end{array}$ & & & & $-0,48$ & & & 0,64 \\
\hline $\begin{array}{l}\text { 7. A jövóben is szívesen dolgoznék } \\
\text { együtt a partneremmel. }\end{array}$ & & & & & 0,67 & & 0,68 \\
\hline $\begin{array}{l}\text { 6. Éreztem, hogy mindkettónknek } \\
\text { jól kell teljesítenie. }\end{array}$ & & & & & 0,62 & & 0,51 \\
\hline 8. Éreztem, hogy jól teljesítünk. & & & & & 0,50 & & 0,59 \\
\hline $\begin{array}{l}\text { 5. Jól tudtunk kommunikálni } \\
\text { a tevékenység alatt. }\end{array}$ & & & & & 0,50 & & 0,50 \\
\hline $\begin{array}{l}\text { 2. Automatikusan együtt tudtunk } \\
\text { múködni a partneremmel. }\end{array}$ & & & & & 0,49 & & 0,49 \\
\hline
\end{tabular}


2. táblázat folytatása

\begin{tabular}{|l|c|c|c|c|c|c|c|}
\hline & \multicolumn{5}{|c|}{ Faktortöltés } & Kommu- \\
\cline { 2 - 7 } & 1 & 2 & 3 & 4 & 5 & 6 & 0,4 altás \\
\hline $\begin{array}{l}\text { 32. Azt éreztem, hogy ketten } \\
\text { jobban teljesítünk, mint egyedül. }\end{array}$ & & & & & 0,48 & & 0,46 \\
\hline $\begin{array}{l}\text { 1. Élvezetesebbnek találtam a közös } \\
\text { tevékenységet, mint azt, amit } \\
\text { egyedül csinálok. }\end{array}$ & & & & & 0,41 & & 0,30 \\
\hline $\begin{array}{l}\text { 39. El tudtam fogadni a partnerem } \\
\text { képességeit. }\end{array}$ & & & & & & $-0,63$ & 0,58 \\
\hline $\begin{array}{l}\text { 19. Jól tudtam reagálni a partnerem } \\
\text { viselkedésére. }\end{array}$ & & & & & & $-0,55$ & 0,57 \\
\hline $\begin{array}{l}\text { 20. Éreztem, hogy számíthatok } \\
\text { a partneremre. }\end{array}$ & & & & & & $-0,53$ & 0,66 \\
\hline 40. Jól tudtunk együttmúködni. & & & & & & $-0,52$ & 0,72 \\
\hline Sajátérték & 11,21 & 2,19 & 1,51 & 1,29 & 0,23 & 1,00 & \\
\hline \% a teljes varianciának & 41,50 & 8,11 & 5,58 & 4,78 & 4,57 & 3,71 & \\
\hline Teljes variancia \% & & & & & & 68,23 & \\
\hline
\end{tabular}

Megjegyzés. Becslési módszer: maximum likelihood; forgatási módszer: oblimin Kaiser normalizációval. A 23., dólt betúvel jelölt tétel a FSZK-39 verziójából kizárásra került.

31., 33., 35., 37., 41.), egy tétel pedig alacsony faktortöltéssel rendelkezett (3. tétel $=0,24)$. A FSZK végsố struktúrájához (2. táblázat) 16 lépésben jutottunk el. A végső tételgyújitemény $\mathrm{KMO}(=0,93)$ és Bartlett-teszt $\left[\chi^{2}(351)\right.$ $=4587,61 ; \mathrm{p}<0,001]$-mutatója megfeleló volt. Ebben a fázisban a FSZK 27 tételt tartalmazott, melyból egyet kizártunk (23. tétel), mivel a késóbbi elemzések és értelmezés során problémás lehet a megtartása. Az említett tétel meglehetósen hasonló volt egy másik itemhez (13. tétel), továbbá a résztvevók is zavarónak jelezték a két tétel hasonlóságát a nyitott kérdésekre adott válaszaikban. A kérdôív kidolgozásának ebben a fázisában a célunk a tételek tisztázása, nem pedig stabil faktorok feltárása volt, így a struktúra nem került értelmezésre.

A 26-tételes FSZK-t további 13 állítással egészítettünk ki a 3. vizsgálat önbeszámolói alapján, így a 4. kutatás során a kérdőív 39-tételes verzióját használtuk az 1709 fốs minta vizsgálatára. Az adatokon feltáró faktorelemzést futtattunk, maximum likelihood becslési módszerrel, promax forgatással $(\mathrm{K}=4)$. A KMO-teszt eredménye 0,96, a Bartlett-teszt szignifikáns $\left[\chi^{2}(741)=39342,64 ; p<0,001\right]$. Az elsó elemzés ötfaktoros megoldást eredményezett. Az 1., 28. és 25 . tételek kommunalitása alacsony volt $(<0,25)$, így kizárásra kerültek. Néhány tétel egynél több faktorra töltött $(5,7,22$, 
23., 29., 33.), és az egyik állítás alacsony faktortöltéssel bírt (35. tétel: 0,18). A FSZK végsó struktúrája 25 tételt tartalmaz, mely öt, jól interpretálható tételból épül fel (3. táblázat). A faktorok belsô konzisztencia mutatói pszichometriailag elfogadhatók (4. táblázat).

3. táblázat. A végső, 28-tételes FSZK itemeinek

kommunalitása és faktortöltései $(\mathrm{N}=1709)$

\begin{tabular}{|c|c|c|c|c|c|c|c|}
\hline & \multirow[t]{2}{*}{ Tételek } & \multicolumn{5}{|c|}{ Faktortöltés } & \multirow{2}{*}{$\begin{array}{l}\text { Kommu- } \\
\text { nalitás }\end{array}$} \\
\hline & & 1 & 2 & 3 & 4 & 5 & \\
\hline \multirow{12}{*}{$\begin{array}{l}\text { 1. Hatékonyság és } \\
\text { összehangoltság } \\
\text { a partnerrel } \\
\text { (12 tétel) }\end{array}$} & $\begin{array}{l}\text { 16. Jól tudtunk együttmú- } \\
\text { ködni. }\end{array}$ & 0,93 & & & & & 0,73 \\
\hline & $\begin{array}{l}\text { 15. Szívesen dolgoznék } \\
\text { együtt máskor is a partne- } \\
\text { remmel. }\end{array}$ & 0,87 & & & & & 0,75 \\
\hline & $\begin{array}{l}\text { 26. A jövốben is szívesen } \\
\text { dolgoznék együtt a partne- } \\
\text { remmel. }\end{array}$ & 0,82 & & & & & 0,73 \\
\hline & $\begin{array}{l}\text { 11. Éreztem, hogy számítha- } \\
\text { tok a partneremre. }\end{array}$ & 0,78 & & & & & 0,59 \\
\hline & $\begin{array}{l}\text { 18. Érzem a kettônk közötti } \\
\text { összhangot. }\end{array}$ & 0,67 & & & & & 0,67 \\
\hline & $\begin{array}{l}\text { 4. Éreztem a kölcsönös bizal- } \\
\text { mi kapcsolatot. }\end{array}$ & 0,66 & & & & & 0,54 \\
\hline & $\begin{array}{l}\text { 19. Jól tudunk kommunikál- } \\
\text { ni a tevékenység alatt. }\end{array}$ & 0,62 & & & & & 0,46 \\
\hline & $\begin{array}{l}\text { 3. Automatikusan együtt } \\
\text { tudunk múködni a partne- } \\
\text { remmel. }\end{array}$ & 0,61 & & & & & 0,48 \\
\hline & $\begin{array}{l}\text { 10. El tudtam fogadni } \\
\text { a partnerem képességeit. }\end{array}$ & 0,59 & & & & & 0,41 \\
\hline & $\begin{array}{l}\text { 17. Jól tudtam reagálni a } \\
\text { partnerem viselkedésére. }\end{array}$ & 0,57 & & & & & 0,48 \\
\hline & $\begin{array}{l}\text { 13. Éreztem, hogy jól } \\
\text { teljesítünk. }\end{array}$ & 0,47 & & & & & 0,48 \\
\hline & $\begin{array}{l}\text { 2. Éreztem, hogy jobb lett a } \\
\text { kapcsolatunk a partneremmel. }\end{array}$ & 0,38 & & & & & 0,38 \\
\hline \multirow{5}{*}{$\begin{array}{l}\text { 2. Bevonódás- } \\
\text { élmény és } \\
\text { koncentráció } \\
\text { (5 tétel) }\end{array}$} & 38. Teljesen kikapcsoltam. & & 0,87 & & & & 0,67 \\
\hline & $\begin{array}{l}\text { 37. Belefeledkeztem } \\
\text { a tevékenységbe. }\end{array}$ & & 0,69 & & & & 0,52 \\
\hline & $\begin{array}{l}\text { 24. A feladat végzése } \\
\text { feltöltött. }\end{array}$ & & 0,69 & & & & 0,58 \\
\hline & $\begin{array}{l}\text { 14. A feladat végeztével több } \\
\text { energiát éreztem magam- } \\
\text { ban, mint a kezdetekor. }\end{array}$ & & 0,57 & & & & 0,39 \\
\hline & $\begin{array}{l}\text { 30. Csak a közös tevékeny- } \\
\text { ségre koncentráltam. }\end{array}$ & & 0,44 & & & & 0,35 \\
\hline
\end{tabular}




\section{3. táblázat folytatása}

\begin{tabular}{|c|c|c|c|c|c|c|c|}
\hline & \multirow[t]{2}{*}{ Tételek } & \multicolumn{5}{|c|}{ Faktortöltés } & \multirow{2}{*}{$\begin{array}{l}\text { Kommu- } \\
\text { nalitás }\end{array}$} \\
\hline & & 1 & 2 & 3 & 4 & 5 & \\
\hline \multirow{3}{*}{$\begin{array}{l}\text { 3. Motiváció és } \\
\text { pozitív hatás a } \\
\text { partnerre ( } 3 \text { tétel) }\end{array}$} & $\begin{array}{l}\text { 27. Motiváltam a partnere- } \\
\text { met a feladat végzése során. }\end{array}$ & & & 0,79 & & & 0,66 \\
\hline & $\begin{array}{l}\text { 36. Éreztem, hogy pozitívan } \\
\text { hatok a partnerem feladat- } \\
\text { végzésére. }\end{array}$ & & & 0,71 & & & 0,62 \\
\hline & $\begin{array}{l}\text { 8. Éreztem, hogy pozitív } \\
\text { hatással vagyok a partnerem } \\
\text { teljesítményére. }\end{array}$ & & & 0,69 & & & 0,57 \\
\hline \multirow{4}{*}{$\begin{array}{l}\text { 4. Motiváció és } \\
\text { tanulás a személy } \\
\text { számára ( } 4 \text { tétel) }\end{array}$} & $\begin{array}{l}\text { 21. A partnerem teljesítmé- } \\
\text { nye ösztönzött. }\end{array}$ & & & & 0,77 & & 0,68 \\
\hline & $\begin{array}{l}\text { 20. A partnerem motivált a } \\
\text { tevékenység végzése során. }\end{array}$ & & & & 0,68 & & 0,66 \\
\hline & $\begin{array}{l}\text { 32. Ellestem néhány fogást } \\
\text { a partneremtôl. }\end{array}$ & & & & 0,51 & & 0,38 \\
\hline & $\begin{array}{l}\text { 6. Tudtam tanulni } \\
\text { a partneremtól. }\end{array}$ & & & & 0,51 & & 0,43 \\
\hline \multirow{4}{*}{$\begin{array}{l}\text { 5. Koordináció a } \\
\text { partnerrel } \\
\text { a tevékenység } \\
\text { közben (4 tétel) }\end{array}$} & $\begin{array}{l}\text { 12. Azt éreztem, hogy szinte } \\
\text { együtt rezdülünk a partne- } \\
\text { remmel. }\end{array}$ & & & & & 0,66 & 0,69 \\
\hline & $\begin{array}{l}\text { 9. Összhangban éreztem a } \\
\text { mozgásomat a partneremével. }\end{array}$ & & & & & 0,61 & 0,57 \\
\hline & $\begin{array}{l}\text { 31. Koordináltuk a mozgá- } \\
\text { sunkat. }\end{array}$ & & & & & 0,54 & 0,42 \\
\hline & $\begin{array}{l}\text { 34. Egymás tükörképének } \\
\text { éreztem magunkat. }\end{array}$ & & & & & 0,52 & 0,39 \\
\hline \multicolumn{2}{|l|}{ Sajátérték } & 11,79 & 2,10 & 1,34 & 1,21 & 1,13 & \\
\hline \multirow{2}{*}{\multicolumn{2}{|c|}{$\begin{array}{l}\text { A faktor által magyarázott variancia } \\
\text { Az összes magyarázott variancia }\end{array}$}} & 42,10 & 7,35 & 4,79 & 4,32 & 4,04 & \\
\hline & & & & & & 62,60 & \\
\hline
\end{tabular}

Megjegyzés: Becslési módszer: maximum likelihood; forgatási módszer: promax Kaiser-normalizációval

4. táblázat. A FSZK és FÁK skáláinak leíró statisztikája, a normalitásvizsgálat eredményével $(\mathrm{N}=1709)$

\begin{tabular}{|c|c|c|c|c|c|c|c|}
\hline Kérdőív & Skála & Átlag & Szórás & $\alpha$ & W & $\mathrm{df}$ & $\mathrm{p}$ \\
\hline \multirow{6}{*}{ FSZK } & $\begin{array}{l}\text { 1. Hatékonyság és összehangoltság } \\
\text { a partnerrel }\end{array}$ & 4,29 & 0,59 & 0,93 & 0,91 & 1709 & $<0,001$ \\
\hline & 2. Bevonódás-élmény és koncentráció & 3,84 & 0,80 & 0,83 & 0,96 & 1709 & $<0,001$ \\
\hline & $\begin{array}{l}\text { 3. Motiváció és pozitív hatás } \\
\text { a partnerre }\end{array}$ & 4,09 & 0,72 & 0,82 & 0,93 & 1709 & $<0,001$ \\
\hline & $\begin{array}{l}\text { 4. Motiváció és tanulás a személy } \\
\text { számára }\end{array}$ & 4,06 & 0,69 & 0,80 & 0,93 & 1709 & $<0,001$ \\
\hline & $\begin{array}{l}\text { 5. Koordináció a partnerrel } \\
\text { a tevékenység közben }\end{array}$ & 3,48 & 0,83 & 0,81 & 0,98 & 1709 & $<0,001$ \\
\hline & Összesített pontszám & 4,12 & 0,75 & 0,94 & 0,97 & 1709 & $<0,001$ \\
\hline \multirow{3}{*}{ FÁK } & 1. Kihívás-készség egyensúly & 3,56 & 0,50 & 0,84 & 0,97 & 1709 & $<0,001$ \\
\hline & 2. Egybeolvadás az élménnyel & 4,00 & 0,60 & 0,84 & 0,96 & 1709 & $<0,001$ \\
\hline & Összesített pontszám & 7,75 & 0,91 & 0,87 & 0,96 & 1709 & $<0,001$ \\
\hline
\end{tabular}

Megjegyzés: $=$ Cronbach- $\alpha ; \mathrm{W}=$ Shapiro-Wilk teszt; $\mathrm{df}=$ szabadságfok; $\mathrm{p}=$ szignifikancia-érték. 
A Shapiro-Wilk-teszt szerint a FSZK és a FÁK alskálái nem követik a normális eloszlást (4. táblázat), így a skálák közötti kapcsolatot Spearman-féle rangkorrelációs elemzéssel teszteltük. A FSZK alskáláinak korrelációs táblázatában közepes, közepesen magas értékekig figyelhetók meg az öszszefüggések a kérdôív alskálái között (5. táblázat).

5. táblázat. A FSZK alskálái közötti korreláció ( $\mathrm{N}=1709)$

\begin{tabular}{|l|c|c|c|c|c|}
\hline \multirow{2}{*}{} & $\begin{array}{c}1 . \\
\text { faktor }\end{array}$ & $\begin{array}{c}2 . \\
\text { faktor }\end{array}$ & $\begin{array}{c}3 . \\
\text { faktor }\end{array}$ & $\begin{array}{c}4 . \\
\text { faktor }\end{array}$ & $\begin{array}{c}5 . \\
\text { faktor }\end{array}$ \\
\cline { 2 - 6 } & \multicolumn{5}{|c|}{$\mathrm{r}_{\mathrm{S}}$} \\
\hline $\begin{array}{l}\text { 1. Hatékonyság és összehangoltság a } \\
\text { partnerrel }\end{array}$ & & & & & \\
\hline 2. Bevonódás-élmény és koncentráció & $0,55^{* *}$ & & & & \\
\hline $\begin{array}{l}\text { 3. Motiváció és pozitív hatás } \\
\text { a partnerre }\end{array}$ & $0,61^{* *}$ & $0,49^{*}$ & & & \\
\hline $\begin{array}{l}\text { 4. Motiváció és tanulás } \\
\text { a személy számára }\end{array}$ & $0,63^{* *}$ & $0,50^{* *}$ & $0,49^{* *}$ & & \\
\hline $\begin{array}{l}\text { 5. Koordináció a partnerrel } \\
\text { a tevékenység közben }\end{array}$ & $0,60^{* *}$ & $0,59^{*}$ & $0,52^{* *}$ & $0,52^{*}$ & \\
\hline
\end{tabular}

Megjegyzés: ${ }^{*} \mathrm{p}<0,05 ;{ }^{* *} \mathrm{p}<0,01 ; \mathrm{r}_{\mathrm{S}}=$ Spearman-féle rangkorrelációs együttható.

A flow-szinkronizáció (FSZK-skálák) konvergens validitását az áramlat-élmény faktoraival teszteltük, a FÁK skálái segítségével. A Spearman-féle rangkorrelációs elemzés szerint (6. táblázat) gyenge-közepesen erós kapcsolat $\left(0,12 \leq \mathrm{r}_{\mathrm{s}} \leq 0,60\right)$ található a flow és a flow-szinkronizáció skálái között.

6. táblázat. A FSZK és a FÁK alskálái közötti korreláció (N = 1709)

\begin{tabular}{|l|c|c|c|}
\hline \multirow{2}{*}{\multicolumn{1}{|c|}{ FSZK }} & \multicolumn{3}{c|}{ FÁK } \\
\cline { 2 - 4 } & $\begin{array}{c}\text { 1. Kihívás- } \\
\text { készség } \\
\text { egyensúly }\end{array}$ & $\begin{array}{c}\text { 2. Egybe- } \\
\text { olvadás a } \\
\text { feladattal }\end{array}$ & $\begin{array}{c}\text { FÁK-össz- } \\
\text { pontszám }\end{array}$ \\
\cline { 2 - 4 } & \multicolumn{2}{|c|}{$\mathrm{r}_{\mathrm{S}}$} \\
\hline $\begin{array}{l}\text { 1. Hatékonyság és összehangoltság } \\
\text { a partnerrel }\end{array}$ & $0,34^{* *}$ & $0,41^{* *}$ & $0,46^{* *}$ \\
\hline 2. Bevonódás-élmény és koncentráció & $0,31^{* *}$ & $0,60^{* *}$ & $0,57^{* *}$ \\
\hline 3. Motiváció és pozitív hatás a partnerre & $0,37^{* *}$ & $0,35^{* *}$ & $0,43^{* *}$ \\
\hline $\begin{array}{l}\text { 4. Motiváció és tanulás a személy } \\
\text { számára }\end{array}$ & $0,12^{* *}$ & $0,37^{* *}$ & $0,32^{* *}$ \\
\hline $\begin{array}{l}\text { 5. Koordináció a partnerrel } \\
\text { a tevékenység közben }\end{array}$ & $0,30^{* *}$ & $0,36^{* *}$ & $0,41^{* *}$ \\
\hline FSZK-összpontszám & $0,35^{* *}$ & $0,53^{* *}$ & $0,55^{* *}$ \\
\hline
\end{tabular}

Megjegyzés: ** $\mathrm{p}<0,01 ; \mathrm{r}_{\mathrm{S}}=$ Spearman-féle rangkorrelációs együttható. 


\section{Megbeszélés}

Jelen munkában egy olyan önbeszámolós kérdőív kidolgozási folyamatát mutattuk be, mellyel célunk a flow-szinkronizáció hipotetikus konstruktumának operacionalizálása. Az eredmények szerint a Flow Szinkronizáció Kérdôív alkalmas méróeszköz lehet a flow-szinkronizáció konzisztens méréséhez. A kérdőív célja azoknak a tényezôknek a megragadása, melyek a közös, interakciót igénylő feladatok során megfigyelhetó áramlat-élményt (Csikszentmihalyi, 1990) támogatják. Feltételezzük, hogy az interakciós helyzetból fakadó, áramlatot támogató tényezók operacionalizálásával az optimális élményról szóló elmélet kiterjeszthetô az egyéni szituációkon kívülre is. A FSZK hasznos lehet azoknak a kutatóknak, akik a flow-élményt interaktív tevékenységek során, a részt vevő személyek diádikus perspektívájából kívánják megragadni, hiszen a diád az interakció legkisebb egysége (Kenny, Kashy, \& Cook, 2006).

Összegzésként elmondható, hogy a kérdóív kidolgozása során mind a racionális, mind pedig az empirikus tesztszerkesztési stratégiákat is alkalmaztuk. A kidolgozás négy fázison keresztül történt, összesen 2227 fó bevonásával vizsgáltuk a méróeszköz megfelelőségét. A kérdőív végső verziója (lásd a Függelékben) 28-tételes, mely tételek 5 faktorba tömörülnek. A vizsgálati személyek az instrukció elolvasása után az egyes állításokat ötfokú Likert-skálán értékelik (fordított tétel nincs). A kérdőívnek és skáláinak reliabilitása megfeleló.

A kidolgozási folyamat alatt a FSZK 42-tételes verziója elsó elemzésének eredménye a skálák finomítása volt, majd a második fázisban a kérdơív dimenzionalitásának feltárását túztük ki célul (Conway \& Huffcutt, 2003). Az elemzés során a faktorok korrelálhattak egymással, mivel feltételezésünk szerint a flow-szinkronizáció konstruktuma számos összefüggó változóból áll, melyek az adott mechanizmus különbözó jellemzóit írják le. Az eredmények szerint tehát a flow-szinkronizációt mérô Flow Szinkronizáció Kérdoóiv 28 tételból és öt latens faktorból épül fel. Az első faktor 12 tételes, melyek közös jelentését a „Hatékonyság és összehangoltság a partnerrel" címkével írjuk le. A tételek információt biztosítanak a partnerek kapcsolódásáról és dinamikus kooperációjáról - személyes és kapcsolati perspektívából.

Korábbi javaslatok szerint (Graham, 2008) a kapcsolat alapvetó tényezốje lehet a növekedésnek és énkiterjesztésnek, mivel pozitív összefüggés van az aktivációs szint, a flow (mely az énkiterjesztést a kihívást keltó tevékenység útján biztosítja) és az élmény minősége között. Ez a faktor reflektálhat az együttes élmény (Mérei, 1947) hozzáadott értékére, mikor két személy egy közös élményben kapcsolódik össze. A faktor néhány tétele 
specifikusabban utal a partneri kapcsolat fejlesztésére és szorosságára. Ez az eredmény leginkább Moore és munkatársainak (2005) hipotézisével függ össze, mely szerint a kapcsolati flow-t leginkább a motiváció fogalmán keresztül érthetjük meg, mivel a másokkal való kapcsolat inspirálhatja a kapcsolati optimizmust és hatékonyságot. A humanisztikus pszichológia képviselói szintén hangsúlyozták a szeretet és valahová tartozás élményét (Maslow, 1968), így ezen előzményekre reflektálva, egy kapcsolat erősítésének kiemelkedó szerepét a valahová tartozás szükséglete indokolhatja, amely az interperszonális kapcsolódás iránti vágyként mint alapvetố humán motivációként jelentkezik (Baumeister \& Leary, 1995). A közös élmény egy következó lehetséges interperszonális akció alapját jelentheti, melyen keresztül a két személy közös emlékekkel rendelkezhet és a viszonyítás útján építheti a kapcsolatot kettójük között (Mérei, 1947).

A második, 5 tételból álló faktor a „Bevonódás-élmény és koncentráció”, tehát ez a skála a tevékenységhez köthetó, mely leginkább a flow-élmény kulcsszempontjait foglalja össze, mivel a személy az elkötelezôdés és koncentráció elemeiról számol be (Csikszentmihalyi, 1990; Csikszentmihalyi és mtsai, 2005; Nakamura \& Csikszentmihalyi, 2002), valamint a szubjektív élmény következményeiról (Fredrickson, 1998). Ez a faktor korrelál legszorosabban a FÁK összpontszámával és az „Egybeolvadás az élménnyel” skálával, mely szintén a flow-szinkronizáció konstruktum flow-hoz mint szubjektív élményhez kapcsolódó tartalmát igazolhatja.

A FSZK harmadik és negyedik faktora a kihívást jelentó helyzetben való közös feladatmegoldást írja le, motivációs szempontból. A harmadik faktor 3 tételból áll, a „Motiváció és pozitív hatás a partnerre” címkét kapta, mely a személy motivációs hatását jelöli a partnerére vonatkozóan. A negyedik, 4-tételes faktor neve a "Motiváció és tanulás a személy számára", mely a válaszadó személy fejlődését takarja a közös tevékenység alatt, melyet a partnere indukál. A flow-élmény egyik kulcseleme a motiváció (Csikszentmihalyi, 1990). Az optimális élmény emergens motiváción alapul, a személy-környezet interakció alkotja azt a dinamikus rendszert, mely (Nakamura \& Csikszentmihalyi, 2002) biztosítja a tevékenységben a következó lépést: a visszajelzést, melyen keresztül a személy megtalálhatja az új célt, és amely a növekvô kihívásokkal járó készségfejlődésre utal. A közös tevékenység alatt a másik személy lehet a környezetben az az ágens, amely visszajelzést, növekvố kihívást biztosít, motiválja a személyt új célok elérésére az önfejlesztés útján (Csikszentmihalyi \& Csikszentmihalyi, 1988), továbbá a tevékenység alatt a partnerek facilitálhatják is egymás flow-élményét (Wesson \& Boniwell, 2007), azáltal, hogy megosztják egymással a készségeiket, hiszen mindketten szükségesek a közös cél eléréséhez a tevékenység során. 
Az ötödik faktor 4 tételt tartalmaz, a „Koordináció a partnerrel a tevékenység során" címkét viseli, mivel a partnerek viselkedéses koordinációjára reflektál a közös tevékenység során. Ez a skála a szociális koordinációs elmélethez kapcsolódóan (Ackerman \& Bargh, 2010), mely egy adott viselkedési akció másolását vagy a kiegészítését hangsúlyozza a koordináció elemeiként. Jelen faktorhoz tartozó tételek a viselkedéses harmonizációt és reflexiót tartalmazzák, mely a flow-szinkronizáció lényeges eleme lehet a tevékenység során, az emberek természetes koordinációs hajlamának eddig nem tárgyalt típusaként. Korábbi eredmények szerint az emberek képesek kódolni mások akcióit, az általuk képviselt célok tekintetében (Hassin, Aarts, \& Ferguson, 2005), így a koordinációs megnyilvánulások a kihívást jelentố cél elérését támogathatják.

Feltételezhető, hogy a FSZK skálái metafaktorokba rendeződnek, hiszen a flow-szinkronizációt három különböző perspektívából írják le: az egyik áttekintô faktor a kihívást jelentô közös tevékenység feladathoz kapcsolódó jellemzóit jelölheti, a második inkább a személyes és együttmúködó jellemzókre koncentrál, míg a harmadik metafaktor a motivációs hatásokat vizsgálhatja. A kérdốív végsó verziója az elózetes elméleti megfontolásokhoz és az empirikus eredményekhez egyaránt illeszkedik, mivel a latens változók a szinkronizáció és koordináció folyamatához kapcsolódnak, a kapcsolat minôségén, a flow-élményen és a partnerek teljesítményt facilitáló hatásán keresztül.

A FSZK-t pszichometriai szempontból is teszteltük: lényeges eredményként közöljük, hogy a flow-szinkronizáció konvergens validitása a flow konstruktumához kapcsolódóan elfogadható volt, mivel közepes erósségú korrelációs együtthatókat eredményezett az elemzés, tehát a két méróeszköz különböző célokat szolgál: a FẤK a flow-élmény komponenseit méri, míg a FSZK a közös helyzetben tapasztalt flow-élményt támogató faktorokat és kísérő mechanizmusát méri. Meg kell jegyeznünk, hogy a FSZK elkötelezettséget jelölő faktora kötődik leginkább a FÁK egybeolvadás faktorához és a FÁK összpontszámához, mivel a flow-szinkronizáció az élmény koordinációjára utal a közös helyzetekben. A konstruktumvaliditás tartalmi elemeihez kapcsolódóan ki kell emelnünk, hogy a kérdôív látszatérvényességét teszteltük, mely a résztvevói és szakértói csoport szerint megfelelố. A tételek belső konzisztenciája a pszichometriai kritériumoknak eleget tesz, minden egyes skála esetében. Mivel a flow-szinkronizáció új konstruktum a pszichológiában, a referenciateszttel való kritérium validitásának tesztelése nem elérhetó, azonban a FSZK végsó verziójának feltáró faktorelemzése támogatta a korábbi, elméleti alapú hipotéziseinket a konstruktum struktúrájára vonatkozóan. 
Hangsúlyozandó, hogy az áramlat-élmény továbbra is szubjektív, egyéni élményként értelmezendő, azonban, ahogyan a vizsgálataink következtetni engednek rá, az interakciós helyzet bizonyos sajátosságai támogathatják, intenzitását növelhetik. A Flow Szinkronizáció Kérdóívvel célunk a feltételezhetően flow-helyzetben zajló, interakcióból következó tényezók megragadása. A kutatások során lényeges szempont a személy-környezet interakciót bóvítô faktorokon, azaz a flow-szinkronizációs elemeken túl a flow-élmény egyéni aspektusának megragadása is, az élmény feltételeit és dinamikáját vizsgáló mérőeszköz segítségével (ahogyan jelen vizsgálatokban is a Flow Állapot Kérdôív alkalmazásával azonosítottuk a flow feltételeit és kísérójelenségeinek intenzitását - Magyaródi és mtsai, 2013).

A Flow Szinkronizáció Kérdőív a jelen munkában közölt kutatássorozat eredményeként megbízható és feltehetóleg érvényes méróeszközt jelenthet a két személy közötti élménymechanizmus mérésére a közös, flow-élményt indukáló tevékenységekben. Mindamellett számos hiányosságot is meg kell fontolnunk, hiszen a kérdóív egy új pozitív pszichológiai konstruktum konceptualizálását és operacionalizálását túzi ki célul. A kidolgozási folyamat négy különböző vizsgálat során történt: az elméleti tételkonstrukciót az empirikus módon nyert tételekkel való kiegészítés és tesztelés követte. Mivel a mintavétel nem valószínúségi módszerekkel történt egyik vizsgálat esetében sem, az eredményeket elóvigyázatosan kell kezelnünk. Megjegyzendő továbbá, hogy abban az esetben, ha a kérdóíveket rögtön a tevékenység után töltik ki, magasabb validitással bírnak, így a harmadik és negyedik vizsgálat retrospektív jellege problémát okozhat a validitási kritérium tekintetében, és különbözhet a laboratóriumi vizsgálatok eredményeitól, ahol közvetlenül az élmény után történt annak értékelése. Ezekhez a hiányosságokhoz kapcsolódóan azt a következtetést vonjuk le, hogy több olyan vizsgálat szükséges, amely a szituáció-válasz elrendezés lehetôségét biztosíthatja, hogy a retrospektív válaszok torzító hatását csökkenteni tudjuk. Mivel kialakítás alatt lévố konstruktumról van szó, így elengedhetetlen a konstruktum további konvergens és diszkrimináns validitásának ellenórzése.

Összefoglalásként hangsúlyozzuk, hogy az előzetes eredmények támogatják a flow-szinkronizáció koncepciójának multidimenzionalitását. Az interpretált faktorok összhangban vannak a vizsgálatokban részt vevók kvalitatív beszámolóival, mivel a szinkronizáció és koordináció, a bevonódás és koncentráció, a motivációs és kapcsolati faktorokat emelte ki az elemzés a közös, kihívást jelentó élmények legspecifikusabb összetevóiként. A jövóbeni kutatásoknak a flow-szinkronizáció struktúrájára kell fókuszálnia; a feltáró faktorelemzés jelenlegi eredményei három lehetséges metafaktort takarhatnak. A következó vizsgálatokban szükséges a faktorstruktúra meg- 
erôsítése, továbbá a feltételezett metastruktúra igazolása. A validitástesztelés következô lépését a jelenlegi felépítés stabilitásának ellenơrzéséhez szükséges megerősítő faktorelemzés jelentheti, mely a flow-szinkronizáció konvergens és diszkriminációs validitásához is hozzájárulhat.

Kitekintésként megfogalmazható az a hipotézis, miszerint egy személy minél többször tapasztalja társas helyzetekben a flow-élményt a flow-szinkronizáció mechanizmusa által kísérve, annál magasabb lesz a közös jóllét szintje (Seligman \& Csikszentmihalyi, 2000) - összhangban a pozitív pszichológia legalapvetóbb céljával. Kutatási eredmények bizonyítják, hogy a sikeres együttmúködés olyan biokémiai folyamatokat indít el, amelyek a jó egészségi állapot fenntartásához is hozzájárulnak (Bauer, 2012), tehát elképzelhetô, hogy mind a fizikai, mind pedig a mentális egészség támogatható az intenzívebb flow és flow-szinkronizáció átélése, az együttmúködést igénylő interakciós helyzetek gyakoribb megtapasztalása segítségével. Feltételezésünk igazolására és a jelenség tanulmányozására szükséges a Flow Szinkronizáció Kérdóív fejlesztése és alkalmazása, a pozitív pszichológia e lehetséges új konstruktumának mérése céljából.

\section{Irodalom}

Ackerman, J.M., \& Bargh, J.A. (2010). Two to tango: Automatic social coordination and the role of felt effort. In B. Bruya (Ed.), Effortless attention - A new perspective in the cognitive science of attention and action (335-371). Cambridge: The MIT Press

Aron, A., \& Aron, E.N. (1986). Love and the expansion of self: Understanding attraction and satisfaction. New York: Hemisphere

Bakker, A.B. (2005). Flow among music teachers and their students: The crossover of peak experiences. Journal of Vocational Behavior, 66, 26-44.

Bakker, A.B. (2008). The work-related flow inventory: Construction and initial validation of the WOLF. Journal of Vocational Behavior, 72, 400-414.

Bauer, J. (2012). Az együttmúködô ember. Alapvetô motivációink a neurobiológiai kutatások fényében. Budapest: Ursus Libris

Baumeister, R.F., \& Leary, M.R. (1995). The need to belong: Desire for interpersonal attachments as a fundamental human motivation. Psychological Bulletin, 117(3), 497-529.

Bernieri, F.J., \& Rosenthal, R. (1991). Interpersonal coordination: Behavior matching and interactional synchrony. In R.S. Feldman, \& B. Rimé (Eds.), Fundamentals of nonverbal behavior. Studies in emotion \& social interaction (401-432). New York: Cambridge University Press

Campos, J.J., \& Sternberg, C.R. (1981). Perception, appraisal and emotion: The onset of social referencing. In M.E. Lamb, \& L.R. Sherrod (Eds.), Infant social cognition: Empirical and theoretical considerations (273-314). Hillsdale, NJ: Erlbaum

Cohen, R.J., \& Swerdlik, M.E. (2009). Psychological testing and assessment: An introduction to tests and measurement (7th ed.). New York: McGraw-Hill-Primis 
Conway, J.M., \& Huffcutt, A.I. (2003). A review and evaluation of exploratory factor analysis practices in organizational research. Organizational Research Methods, 6(2), 147168.

Csikszentmihalyi, M. (1990). Flow: The psychology of optimal experience. New York: Harper \& Row

Csikszentmihalyi, M., \& Csikszentmihalyi, I. (1988). Optimal experience: Psychological studies of flow in consciousness. New York: Cambridge University Press

Csikszentmihalyi, M., Abuhamdeh, S., \& Nakamura, J. (2005). Flow. In A.J. Elliot, \& C.S. Dweck (Eds.), Handbook of competence and motivation (598-608). New York: Guilford Publications

Csikszentmihalyi, M., \& Larson, R. (1987). Validity and reliability of the Experience-Sampling Method. The Journal of Nervous and Mental Disease, 175(9), 526-536.

Csikszentmihalyi, M., \& LeFevre, J. (1989). Optimal experience in work and leisure. Journal of Personality and Social Psychology, 56(5), 815-822.

Delaherche, E., Chetouani, M., Mahdhaoui, A., Saint-Georges, C., Viaux, S., \& Cohen, D. (2012). Interpersonal synchrony: A survey of evaluation methods across disciplines. Affective Computing, 3(3), 349-365.

Dumas, G., Nadel, J., Soussignan, R., Martinerie, J., \& Garnero, L. (2010). Inter-brain synchronization during social interaction. PLOS ONE, 5, e12166.

Engeser, S. (2012). Advances in flow research. New York: Springer

Fredrickson, B.L. (1998). What good are positive emotions? Review of General Psychology, 2(3), 300-319.

Fredrickson, B.L. (2013). Love 2.0: Finding happiness and health in moments of connection. New York: Plume

Gaggioli, A., Milani, L., Mazzoni, E., \& Riva, G. (2011). Networked flow: A framework for understanding the dynamics of creative collaboration in educational and training settings. The Open Educational Journal, 4, 107-115.

Graham, J.M. (2008). Self-expansion and flow in couples' momentary experiences: An experience sampling study. Journal of Personality and Social Psychology, 95, 679-694.

Hassin, R.R., Aarts, H., \& Ferguson, M.J. (2005). Automatic goal inferences. Journal of Experimental Social Psychology, 41, 129-140.

Hasson, U., Ghazanfar, A.A., Galantucci, B., Garrod, S., \& Keysers, C. (2012). Brain-to-brain coupling: A mechanism for creating and sharing a social world. Trends in Cognitive Sciences, 16(2), 114-121.

Hatfield, E., Cacioppo, J.T., \& Rapson, R.L. (1994). Emotional contagion. New York: Cambridge University Press

Hefferon, K.M., \& Ollis, S. (2006). 'Just clicks': An interpretive phenomenological analysis of professional dancer's experience of flow. Research in Dance Education, 7(2), 141-159.

Jackson, S.A., Thomas, P.R., Marsh, H.W., \& Smethurst, C.J. (2001). Relationships between flow, self-concept, psychological skills, and performance. Journal of Applied Sport Psychology, 13, 129-153.

Johnson, D.W., Johnson, R.T., Holubec, E., \& Roy, P. (1984). Circles of learning: Cooperation in the classroom. Alexandria, VA: Association for Supervision and Curriculum Development

Kenny, D.A., Kashy, D.A., \& Cook, W.L. (2006). Dyadic data analysis. New York: Guilford Press

Keyes, C.L.M. (2002). The mental health continuum: From languishing to flourishing in life. Journal of Health and Social Research, 43, 207-222. 
Magyaródi, T., Nagy, H., Soltész, P., Mózes, T., \& Oláh, A. (2013). Psychometric properties of a newly established flow state questionnaire. Journal of Happiness $\mathcal{E}$ Well-Being, 1(2), 85-96.

Maslow, A.H. (1968). Toward a psychology of being. New York: Van Nostrand

Massimini, F., \& Delle Fave, A. (2000). Individual development in a bio-cultural perspective. American Psychologist, 55, 24-33.

McMahan, R.P., Ragan, E.D., Leal, A., Beaton, R.J., \& Bowman, D.A. (2011). Considerations for the use of commercial video games in controlled experiments. Entertainment Computing, 2, 3-9.

Mérei, F. (1947). Az együttes élmény. Budapest: Officina

Moneta, G.B. (2012). On the measurement and conceptualization of flow. In S. Engeser (Ed.), Advances in flow research (23-50). New York: Springer

Moore, M., Drake, D., Tschannen-Moran, B., Campone, F., \& Kaufmann, C. (2005). Relational flow: A theoretical model for the intuitive dance. 2005 Coaching Research Symposium Proceedings. Letöltve: 2015. 07. 20-án: http://www.francinecampone.com/resources/ papers/relational.flow.model-final.pdf

Moreno Murcia, J.A., Cervelló Gimeno, E., \& González-Cutre Coll, D. (2008). Relationships among goal orientations, motivational climate and flow in adolescent athletes: Differences by gender. The Spanish Journal of Psychology, 11(1), 181-191.

Nakamura, J., \& Csikszentmihalyi, M. (2002). The concept of flow. In C.R. Snyder, \& S.J. Lopez (Eds.), Handbook of Positive Psychology (89-105). New York: Oxford University Press

Novak, T.P., \& Hoffman, D.L. (1997). Measuring the flow experience among web users. Letöltve: 2015. 07. 20-án: http:/ / citeseerx.ist.psu.edu/viewdoc/ download?doi =10.1.1.89.1411\&rep $=$ rep $1 \&$ type $=\mathrm{pdf}$

Ramseyer, F., \& Tschacher, W. (2008). Synchrony in dyadic psychotherapy sessions. In S. Vrobel, O.E. Rössler, \& T. Marks-Tarlow (Eds.), Simultaneity: Temporal structures and observer perspectives (329-347). Singapore: Scientific World

Ramseyer, F., \& Tschacher, W. (2010). Nonverbal synchrony or random coincidence? How to tell the difference. In A. Esposito, C. Campbell, A. Vogel, A. Hussain, \& A. Nijholt (Eds.), Development of multimodal interfaces: Active listening and synchrony (182-196). New York: Springer

Salanova, M., Peiró, J.M., \& Schaufeli, W.B. (2002). Self-efficacy specificity and burnout among information technology workers: An extension of the job demand-control model. European Journal of Work and Organizational Psychology, 11, 1-25.

Salanova, M., Rodríguez-Sánchez, A.M., Schaufeli, W.B., Cifre, E. (2014). Flowing together: A longitudinal study of collective efficacy and collective flow among workgroups. The Journal of Psychology, 148(4), 435-455.

Sawyer, R.K. (2007) Group genius: The creative power of collaboration. New York: Basic Books Press

Seligman, M.E.P., \& Csikszentmihalyi, M. (2000). Positive psychology. An introduction. American Psychologist, 55(1), 5-14.

Semin, G.R., \& Cacioppo, J.P. (2008). Grounding social cognition: Synchronization, entrainment, and coordination. In G.R. Semin, \& E.R. Smith (Eds.), Embodied grounding: Social, cognitive, affective, and neuroscientific approaches (119-147). New York: Cambridge University Press

Swann, C., Keegan, R., Piggott, D., Crust, L., \& Smith, M.F. (2011). Exploring flow occurrence in elite golf. Athletic Insight, 4(2), 1-16. 
Trevarthen, C. (1980). The foundations of intersubjectivity: Development of interpersonal and cooperative understanding in infants. In D.R. Olson (Ed.), The social foundation of language and thought (316-342). New York: Norton

Tschacher, W, Rees, G.M., \& Ramseyer, F. (2014). Nonverbal synchrony and affect in dyadic interactions. Frontiers in Psychology, 5, 1323.

Ulrich, M., Keller, J., Hoenig, K., Waller, C., \& Grön, G. (2014). Neural correlates of experimentally induced flow experiences. NeuroImage, 86, 194-202.

Walker, C.J. (2010). Experiencing flow: Is doing it together better than doing it alone? Journal of Positive Psychology, 5(1), 3-11.

Wesson, K., \& Boniwell, I. (2007). Flow theory: Its application to coaching psychology. International Coaching Psychology Review, 2(1), 33-43.

Whalen, S.P. (1998). Flow and the engagement of talent: Implications for secondary schooling. NASSP Bulletin, 82(595), 22-37.

\section{Szerzối munkamegosztás}

Magyaródi Tímea: elméleti és kutatási koncepció megalkotása, kutatástervezés, kézirat megszövegezése, statisztikai elemzések, eredmények értelmezése. Dr. Oláh Attila: elméleti koncepció, hipotézisek megfogalmazása, kutatástervezés, a kézirat ellenórzése.

\section{Nyilatkozat érdekütközésól}

A szerzók ezúton kijelentik, hogy esetükben nem állnak fenn érdekütközések.

\section{Függelék}

\section{Flow Szinkronizáció Kérdốiv}

Gondoljon az elóbbiekben megjelölt közös tevékenységre, és jelölje be egy ötfokú skálán (1: Egyáltalán nem - 5: Teljes mértékben), hogy mennyire jellemzik Önt az alábbi állítások a tevékenység végzése alatt!

1. Egyáltalán nem

2. Nem

3. Semleges

4. Valamennyire

5. Teljes mértékben

1. Éreztem, hogy pozitívan hatok a partnerem feladatvégzésére.

2. A feladat végeztével több energiát éreztem magamban, mint a kezdetekor.

3. A partnerem motivált a tevékenység végzése során.

4. Jól tudunk kommunikálni a tevékenység alatt.

5. A partnerem teljesítménye ösztönzött. 
6. Éreztem a kölcsönös bizalmi kapcsolatot.

7. Ellestem néhány fogást a partneremtól.

8. Egymás tükörképének éreztem magunkat.

9. Összhangban éreztem a viselkedésemet a partneremével.

10. Éreztem, hogy jól teljesítünk.

11. Csak a közös tevékenységre koncentráltam.

12. Szívesen dolgoznék együtt máskor is a partneremmel.

13. Motiváltam a partneremet a feladat végzése során.

14. Éreztem a kettónk közötti összhangot.

15. Koordináltuk a viselkedéses megnyilvánulásainkat.

16. Éreztem, hogy jobb lett a kapcsolatunk a partneremmel.

17. Éreztem, hogy számíthatok a partneremre.

18. A jövóben is szívesen dolgoznék együtt a partneremmel.

19. Automatikusan együtt tudunk múködni a partneremmel.

20. Jól tudtam reagálni a partnerem viselkedésére.

21. Belefeledkeztem a tevékenységbe.

22. Éreztem, hogy pozitív hatással vagyok a partnerem teljesítményére.

23. Azt éreztem, hogy szinte együtt rezdülünk a partneremmel.

24. A feladat végzése feltöltött.

25. Tudtam tanulni a partneremtól.

26. El tudtam fogadni a partnerem képességeit.

27. Jól tudtunk együttmúködni.

28. Teljesen kikapcsolódtam.

\title{
Flow Synchronization Questionnaire: Measuring the mechanism of optimal experience in interactions
}

\author{
MAGYARÓDI, TÍMEA - OLÁH, ATTILA
}

Theoretical background: The study of flow experience in different activities is a wide research area in positive psychology, though its mechanism in interactive situations is still unknown. Aim: To support the quantitative study of the dynamics of optimal experience in challenging, interactive activities, we intended to develop the Flow Synchronization Questionnaire (FSyQ). Methods: The development of this measure was based on both the rational and empirical test establishment traditions. After the first phase of rational test collection, we continued with four empirical studies to investigate the different versions of FSyQ. Altogether, 2077 adults participated in the studies (two laboratory studies: $N_{1}=60 ; N_{2}=100$; two survey studies: $\mathrm{N}_{3}=358 ; \mathrm{N}_{4}=1709$ ). Results: The final version of the measure contains 28 items and 5 latent factors that focus on the motivational and coordination (task- and relationship-focus) aspects of the experience: 1 . Synchronization and effective cooperation with the partner (12 items); 2. Experience of engagement and concentration (5 items); 3. Motivation and positive impact on the partner ( 3 items); 4 . Motivation and learning for the 
person (4 items); 5 . Coordination with the partner during the activity ( 4 items). The internal consistencies of the scales are adequate. The face validity of the questionnaire is also satisfying, its convergent validity related to flow is appropriate, as the scales of FSyQ correlate moderately with the factors of flow. Conclusions: The development of the FSyQ can contribute to the operationalization of the concept of flow synchronization and the future empirical studies of flow in interactive activities.

Keywords: flow, flow synchronization, interaction, questionnaire development 